\title{
Phytotoxic activity and chemical composition of aqueous foliar extracts of Cerrado species
}

\author{
Sharmely Hilares Vargas ${ }^{1}$ \\ Elisangela Clarete Camili ${ }^{1}$ \\ Maria de Fatima Barbosa Coelho ${ }^{1}$ (D) \\ Leonardo Gomes de Vasconcelos ${ }^{2}$ (1) \\ Marcos Antônio Soares ${ }^{3}$ (1) \\ Olivia Suzana Moreira Sampaio ${ }^{2}$ (C) \\ Suzana Junges Vendruscolo ${ }^{3}$ (D)
}

${ }^{1}$ Universidade Federal de Mato Grosso, Programa de Pós-Graduação em Agricultura Tropical, Cuiabá, MT, Brasil.

${ }^{2}$ Universidade Federal de Mato Grosso, Departamento de Química, Cuiabá, MT, Brasil.

${ }^{3}$ Universidade Federal de Mato Grosso, Programa de Pós-Graduação em Ecologia e Conservação da Biodiversidade, Cuiabá, MT, Brasil.

\begin{abstract}
This study aimed to evaluate the phytotoxic activity of aqueous extracts of species from the Cerrado of Mato Grosso on the germination and initial development of lettuce seedlings, as well as to determine the chemical composition of the extracts. The species studied were: Davilla elliptica, Combretum laxum, Himatanthus obovatus, Diteryx alata, Curatella americana, Qualea grandiflora, Aspidosperma macrocarpon, Caryocar brasiliense, Pleroma candolleanum and Miconia albicans. Fourier Transform Infrared Spectroscopy (FTIR) and Thin Layer Chromatography (TLC) techniques were used to identify functional groups and chemical compounds. The extracts of the species D. elliptica, C. laxum, C. brasiliense and Q. grandiflora showed greater phytotoxic activity on the germination of lettuce seeds which varied between 96 and $17 \%$. The presence of compounds such as: phenols, alkaloids, flavonoids and terpenes with phytotoxic properties was confirmed.
\end{abstract}

Keywords: Allelochemicals, bioassays, FTIR, TLC, Lactuca sativa L.

\section{INTRODUCTION AND OBJECTIVES}

Brazil is considered one of the largest producers and exporters of agricultural food (OECD and FAO, 2015). High production implies a large consumption of agricultural inputs for the country, occupying since 2008 the first place in the ranking associated with the use of pesticides for the control of pests and diseases, a fact that has caused environmental problems and human intoxication (Londres, 2011). In the wide range of pesticides used, herbicides are the fastest growing area in the industry and represent $48 \%$ of the market (Gupta, 2017).

As a consequence, there is interest in the search for new alternatives for sustainable weed control (Chaves et al., 2019). One of the most promising alternatives to reduce dependence on synthetic herbicides is the use of plants that allow the development of bioherbicides from their allelochemical potential. In this scenario, there is a growing advance in the search for new species with allelopathic potential, which result in future works of chemical prospecting of the bioactive compounds (Pereira et al., 2018).
Although several phytotoxic studies have already been carried out with Cerrado species (Gatti et al., 2007; Imatomi et al., 2013); there is an enormous wealth of new bioactive products that remain almost unexploited from a phytochemical point of view.

Davilla elliptica, Combretum laxum, Himatanthus obovatus, Diteryx alata, Curatella americana, Qualea grandiflora, Aspidosperma macrocarpon, Caryocar brasiliense, Pleroma candolleanum and Miconia albicans are medicinal species that highly occurring in Cerrado and are adapted to sudden burning in the dry season. Species collected in this area have important reserves of compounds with bioactive potential that can be explored for phytotoxicity, in addition to medicinal properties. Thus, the discoveries will allow not only understanding the complex interactions between species, but also serving as a basis for the production of new herbicides for the sustainable management of weeds.

The objective of this work was to evaluate the phytotoxic activity of aqueous leaf extracts of ten species from the Cerrado of Mato Grosso in different concentrations on the germination and initial development of lettuce seedlings, as well as to determine the chemical composition of the extracts. 


\section{MATERIALS AND METHODS}

To carry out this study, leaves of ten Cerrado species were collected from adult individuals in the municipality of Chapada dos Guimarães, Mato Grosso, Brazil. The collection site correspond to a Cerrado area of natural regeneration. The local climate is Aw according to the Köppen classification, with an average annual temperature of 21.5 to $22.5{ }^{\circ} \mathrm{C}$; average annual rainfall of 1,800 to $2,000 \mathrm{~mm}$ and the soil is classified as a Red Latosol. The collection was carried out in the dry period, between August and September 2018; in the morning, with full sun conditions. The exsiccata of each of the collected species was deposited at the Central Herbarium of UFMT, campus Cuiabá/MT (Table 1).

Table 1. Species from the Cerrado used in the study. Chapada dos Guimarães / MT.

\begin{tabular}{ccccc}
$\mathbf{N}^{\circ}$ & Species & Commom name & Family & Exsiccata \\
\hline 1 & Davilla elliptica A.St.-Hil & lixeirinha & Dilleniaceae & UFMT 44313 \\
2 & Combretum laxum Jacq. & pombeiro-branco & Combretaceae & UFMT 44312 \\
3 & Himatanthus obovatus (Müll. Arg.) Woodson & pau-de-leite & Apocynaceae & UFMT 44362 \\
4 & Dipteryx alata Vogel & cumbaru & Fabaceae & UFMT 44376 \\
\hline 5 & Curatella americana L. & lixeira & Dillineniaceae & UFMT 44363 \\
6 & Qualea grandiflora Mart. & pau-terra & Vochysiaceae & UFMT 44366 \\
7 & Aspidosperma macrocarpon Mart. \& Zucc. & guatambu & Apocynaceae & UFMT 44364 \\
8 & Caryocar brasiliense Cambess. & pequi, grão-de-cavalo & Caryocaraceae & UFMT 44365 \\
9 & Pleroma candolleanum (Mart. ex DC.) Triana & quaresmeira & Melastomataceae & UFMT 44315 \\
10 & Miconia albicans (Sw.) Triana & folha-branca & Melastomataceae & UFMT 44314
\end{tabular}

The fresh leaves of each species were previously disinfected for 5 minutes in a solution with $2.5 \%$ sodium hypochlorite. Then, they were rinsed with distilled water and dried with paper towels. Fifty grams of leaves were crushed in a blender in $500 \mathrm{~mL}$ of distilled water at room temperature during one minute. The crude aqueous extracts, equivalent to $100 \%$ concentrations, were sieved ( $1 \mathrm{~mm}$ mesh) and stored at 18 ${ }^{\circ} \mathrm{C}$ in amber glass bottles, previously identified, until use in bioassays (2 days). Dilutions to 75,50 and $25 \%$ were prepared and distilled water was used as the control treatment $(0 \%)$ (Vargas et al., 2019).

Analysis of $\mathrm{pH}$ and electrical conductivity (EC) were recorded for possible interference with digital $\mathrm{pHmeter}$ model Instruterm pH-2000 and condutivímetro modelo Digimed DM-32. From the EC values, the osmotic potential (PO) was determined using the formula proposed by Ayers and Westcot (1999): osmotic potential in atmosphere (ATM) = -0.36 * EC. ATM data was transformed to Mpa.

Lettuce (Lactuca sativa 'Veneranda') was the specie used as receivers for the bioassays. The experiment was completely randomized design with five treatments $(0,25,50,75$ and $100 \%$ ) with four replications of 25 lettuce seed each.

The seeds were placed in plastic boxes gerbox type $(11 \mathrm{x}$ $11 \times 3 \mathrm{~cm}$ ) on two sheets of blotting paper moistened with the respective treatments in the amount of 2.5 times the mass of the dry substrate. The boxes were sealed with plastic film and kept in a BOD germination chamber at constant temperature of $20^{\circ} \mathrm{C}$ and a photoperiod of 12 hours according to the Rules for Seed Analysis (Brasil, 2009).
The germination was evaluated every 24 hours to calculate the Germination Speed Index (GSI) (MAGUIRE, 1962). After seven days the length of the shoot (SL) and root length (RL) was evaluated with the aid of a graduated ruler in centimetres (BRASIL, 2009). To determine the dry biomass the seedlings were dried in an oven with forced air circulation at $65^{\circ} \mathrm{C}$, where they remained 72 hours. The dry biomass was obtained using a semi-analytical balance $(0.001 \mathrm{~g})$ and expressed in mg. seedling ${ }^{-1}$. The response index to the allelopathic effect (IR) was calculated according to the formula of Williamson and Richardson (1988).

The data were evaluated according to the homogeneity of variance (Levene) and normality (Shapiro-Wilk), for each variable and corresponding donor species, and the data transformation was performed when necessary, adopting the arc-sine angular transformation for percentage (GP). Analysis of variance (ANOVA) was performed applying the $F$ test and Duncan's test $(\mathrm{p}<0.05)$. For non-parametric data, the Mann-Whitney test was performed.

The functional groups present in the aqueous extracts of the four species with the greatest allelopathic effect (C. laxum, D. elliptica, C. brasiliense and Q. grandiflora) were identified. The infrared spectra of the four selected species were obtained using a potassium bromide $(\mathrm{KBr})$ tablet, kiln dried for 24 hours, prepared in the laboratory with the aid of a hydraulic press in the proportion of 100 $\mathrm{mg} \mathrm{KBr}$ to $1 \mathrm{mg}$ of aqueous extracts lyophilized, the $\mathrm{KBr}$ tablet background procedure was initially performed. The analyzes were performed in triplicate using a Shimadzu 
Iraffinity-1 spectrophotometer (Model IRAffinity-1) and the FTIR spectra (Fourier transform infrared spectroscopy) were obtained using the IRSolution software (Version: 1.50), using the following acquisition parameters: Measurement Mode (\% Transmittance); Apodizaiton (Happ_Genzel); Number of Scans (200); Resolution (16); Range (400 to $4000 \mathrm{~cm}^{-1}$ ); Gain (1).

The classes of secondary metabolites were identified by thin layer chromatography (TLC), using silica gel $60,0.20 \mathrm{~mm} \mathrm{~F}_{254}$ as an adsorbent and acetate: methanol 90:20 (v/v), with the addition of a drop of DMF (dimethylformamide). The revelations were carried out with the following developers: vanillin for terpenes, ferric chloride for phenolic compounds, aluminum chloride for flavonoids and Ehrlich reagent for alkaloids.

\section{RESULTS AND DISCUSSION}

The results of the hydrogen potential $(\mathrm{pH})$ and osmotic potential (PO) of the extracts of each species are shown in Table 2. According to Gatti et al. (2004) and Wandscheer et al. (2011), solutions with osmotic potential lower or close to $-0.2 \mathrm{MPa}$ and $\mathrm{pH}$ between 3 and 11 do not interfere in the parameters of lettuce seed germination.

All extracts studied showed values within those mentioned above, and the maximum value of osmotic potential obtained was $-0.04 \mathrm{MPa}$ corresponding to the species $H$. obovatus and A. macrocarpon. Therefore, the results observed in the bioassays correspond to the effect of secondary metabolites present in the extracts and not due to the action of osmotic potential or $\mathrm{pH}$.

Table 2. Hydrogenionic $(\mathrm{pH})$ and osmotic potential (OP) of aqueous extracts obtained from leaves of ten Cerrado species, Chapada dos Guimarães/MT, 2018.

\begin{tabular}{lcc} 
Species & $\mathbf{p H}$ & OP $(\mathbf{M P a})$ \\
\hline Davilla elliptica & 4.63 & -0.03 \\
Combretum laxum & 5.06 & -0.02 \\
Himatanthus obovatus & 4.71 & -0.04 \\
Dipteryx alata & 5.17 & -0.02 \\
Curatella americana & 4.76 & -0.03 \\
Qualea grandiflora & 3.92 & -0.01 \\
Aspidosperma macrocarpon & 3.71 & -0.04 \\
Caryocar brasiliense & 3.72 & -0.03 \\
Pleroma candolleanum & 4.08 & -0.02 \\
Miconia albicans & 4.22 & -0.01 \\
Water (control) & 6.64 & 0.00 \\
\hline
\end{tabular}

For the variable percentage of germination, there was a difference between the concentrations of D. elliptica, C. laxum, C. americana, Q. grandiflora, A. macrocarpon and C. brasiliense extracts, varying between 17 and $99 \%$ of germination (Table 3).

Table 3. Germination percentage (GP, \%), germination speed index (GSI), shoot length (SL, cm), root length (RL, $\mathrm{cm})$ and dry mass (DM, mg seedling ${ }^{-1}$ ) of lettuce seedlings (Lactuca sativa L.) submitted to different concentrations of aqueous leaf extracts from ten Cerrado species. Chapada dos Guimarães/MT, 2018.

\begin{tabular}{|c|c|c|c|c|c|c|c|}
\hline \multirow{2}{*}{ Variavel } & \multicolumn{5}{|c|}{ Concentration (\%) } & \multirow{2}{*}{$P$ value } & \multirow{2}{*}{ CV (\%) } \\
\hline & $\mathbf{0}$ & 25 & 50 & 75 & 100 & & \\
\hline \multicolumn{8}{|c|}{ Davilla elliptica A.St-Hil } \\
\hline GP & $92.0 \mathrm{a}$ & $91.0 \mathrm{a}$ & $88.0 \mathrm{a}$ & $91.0 \mathrm{a}$ & $73.0 \mathrm{~b}$ & 0.00 & 5.6 \\
\hline GSI & $16.6 \mathrm{a}$ & $16.1 \mathrm{a}$ & $15.4 \mathrm{a}$ & $14.0 \mathrm{a}$ & $9.4 \mathrm{~b}$ & 0.00 & 16.0 \\
\hline SL & $2.8 \mathrm{a}$ & $1.5 \mathrm{~b}$ & $1.3 \mathrm{~b}$ & - & - & 0.00 & 13.6 \\
\hline RL & $2.2 \mathrm{a}$ & $2.6 \mathrm{a}$ & $2.7 \mathrm{a}$ & - & - & 0.60 & 29.5 \\
\hline $\mathrm{DM}$ & $0.5 \mathrm{a}$ & $0.4 \mathrm{a}$ & $0.1 \mathrm{~b}$ & - & - & 0.02 & 32.0 \\
\hline \multicolumn{8}{|c|}{ Combretum laxum Jacq. } \\
\hline GP & $92.0 \mathrm{a}$ & $83.0 \mathrm{a}$ & $68.0 \mathrm{~b}$ & $48.0 \mathrm{c}$ & $17.0 \mathrm{~d}$ & 0.00 & 12.0 \\
\hline GSI & $16.6 \mathrm{a}$ & $10.0 \mathrm{~b}$ & $6.4 \mathrm{c}$ & $3.7 \mathrm{~d}$ & $1.1 \mathrm{e}$ & 0.00 & 12.0 \\
\hline SL & $2.8 \mathrm{a}$ & $2.6 \mathrm{a}$ & $2.3 \mathrm{ab}$ & $1.9 \mathrm{~b}$ & - & 0.03 & 14.3 \\
\hline RL & $2.2 \mathrm{~b}$ & $2.3 \mathrm{ab}$ & $3.2 \mathrm{a}$ & $3.2 \mathrm{a}$ & - & 0.01 & 15.2 \\
\hline DM & $0.5 \mathrm{a}$ & $0.3 \mathrm{~b}$ & $0.3 \mathrm{~b}$ & $0.3 \mathrm{~b}$ & - & 0.02 & 40.3 \\
\hline \multicolumn{8}{|c|}{ Himatanthus obovatus (Müll. Arg.) Woodson } \\
\hline GP & $99.0 \mathrm{a}$ & $98.0 \mathrm{a}$ & $98.0 \mathrm{a}$ & $99.0 \mathrm{a}$ & $97.0 \mathrm{a}$ & - & 2.6 \\
\hline GSI & $23.9 \mathrm{a}$ & $23.6 \mathrm{a}$ & $23.3 \mathrm{a}$ & $23.9 \mathrm{a}$ & $22.6 \mathrm{a}$ & - & 5.0 \\
\hline SL & $1.8 \mathrm{ab}$ & $2.0 \mathrm{a}$ & $1.6 \mathrm{~b}$ & $1.5 \mathrm{~b}$ & $1.2 \mathrm{c}$ & 0.00 & 12.3 \\
\hline RL & $3.7 \mathrm{a}$ & $2.1 \mathrm{~b}$ & $1.9 \mathrm{~b}$ & $1.4 \mathrm{c}$ & $1.2 \mathrm{c}$ & 0.00 & 12.7 \\
\hline DM & $0.5 \mathrm{a}$ & $0.6 \mathrm{a}$ & $0.6 \mathrm{a}$ & $0.6 \mathrm{a}$ & $0.6 \mathrm{a}$ & - & 9.5 \\
\hline
\end{tabular}


Table 1. Continued...

\begin{tabular}{|c|c|c|c|c|c|c|c|}
\hline \multirow{2}{*}{ Variavel } & \multicolumn{5}{|c|}{ Concentration (\%) } & \multirow{2}{*}{$P$ value } & \multirow{2}{*}{ CV (\%) } \\
\hline & o & 25 & 50 & 75 & 100 & & \\
\hline \multicolumn{8}{|c|}{ Dipteryx alata Vogel. } \\
\hline GP & $99.0 \mathrm{a}$ & $99.0 \mathrm{a}$ & $98.0 \mathrm{a}$ & $92.0 \mathrm{a}$ & $96.0 \mathrm{a}$ & - & 3.8 \\
\hline GSI & $23.9 \mathrm{a}$ & $18.3 \mathrm{bc}$ & $21.5 \mathrm{ab}$ & $15.1 \mathrm{~cd}$ & $12.7 \mathrm{~d}$ & 0.00 & 12.0 \\
\hline SL & $1.8 \mathrm{a}$ & $1.9 \mathrm{a}$ & $1.8 \mathrm{a}$ & $1.6 \mathrm{a}$ & $1.5 \mathrm{a}$ & 0.16 & 12.6 \\
\hline $\mathrm{RL}$ & $3.7 \mathrm{a}$ & $1.3 \mathrm{~b}$ & $1.4 \mathrm{~b}$ & $1.6 \mathrm{~b}$ & $1.5 \mathrm{~b}$ & 0.00 & 12.3 \\
\hline DM & $0.5 \mathrm{a}$ & $0.5 \mathrm{a}$ & $0.6 \mathrm{a}$ & $0.5 \mathrm{a}$ & $0.5 \mathrm{a}$ & 0.23 & 12.4 \\
\hline \multicolumn{8}{|c|}{ Curatella americana $\mathrm{L}}$. \\
\hline GP & $99.0 \mathrm{a}$ & $98.0 \mathrm{ab}$ & $98.0 \mathrm{ab}$ & $96.0 \mathrm{~b}$ & $96.0 \mathrm{~b}$ & - & 2.3 \\
\hline GSI & $23.9 \mathrm{a}$ & $15.2 \mathrm{~b}$ & $13.0 \mathrm{~b}$ & $11.5 \mathrm{c}$ & $11.0 \mathrm{~d}$ & - & 6.1 \\
\hline SL & $1.8 \mathrm{a}$ & $1.7 \mathrm{ab}$ & $1.4 \mathrm{bc}$ & $1.3 \mathrm{c}$ & $1.3 \mathrm{c}$ & 0.01 & 15.1 \\
\hline $\mathrm{RL}$ & $3.7 \mathrm{a}$ & $1.0 \mathrm{~b}$ & $0.9 \mathrm{~b}$ & $0.9 \mathrm{~b}$ & $1.0 \mathrm{~b}$ & 0.00 & 12.4 \\
\hline DM & $0.5 \mathrm{a}$ & $0.6 \mathrm{a}$ & $0.5 \mathrm{a}$ & $0.5 \mathrm{a}$ & $0.6 \mathrm{a}$ & 0.07 & 11.7 \\
\hline \multicolumn{8}{|c|}{ Qualea grandiflora Mart. } \\
\hline GP & $96.0 \mathrm{a}$ & $91.0 \mathrm{ab}$ & $87.0 \mathrm{bc}$ & $74.0 \mathrm{~cd}$ & $68.0 \mathrm{~d}$ & 0.00 & 9.3 \\
\hline GSI & $13.6 \mathrm{a}$ & $11.9 \mathrm{~b}$ & $10.1 \mathrm{~b}$ & $8.3 \mathrm{c}$ & $6.5 \mathrm{c}$ & 0.00 & 12.4 \\
\hline SL & $2.3 \mathrm{a}$ & $1.8 \mathrm{~b}$ & $1.5 \mathrm{bc}$ & $1.3 \mathrm{c}$ & - & 0.00 & 12.4 \\
\hline RL & $4.2 \mathrm{a}$ & $2.6 \mathrm{~b}$ & $2.6 \mathrm{~b}$ & $1.8 \mathrm{c}$ & - & 0.00 & 16.4 \\
\hline $\mathrm{DM}$ & $0.5 \mathrm{~b}$ & $0.6 \mathrm{ab}$ & $0.6 \mathrm{~b}$ & $0.8 \mathrm{a}$ & - & 0.02 & 13.7 \\
\hline \multicolumn{8}{|c|}{ Aspidosperma macrocarpon } \\
\hline GP & $96.0 \mathrm{a}$ & $91.0 \mathrm{ab}$ & $87.0 \mathrm{bc}$ & $74.0 \mathrm{~cd}$ & $68.0 \mathrm{~d}$ & 0.00 & 9.7 \\
\hline GSI & $13.6 \mathrm{a}$ & $11.5 \mathrm{~b}$ & $10.6 \mathrm{bc}$ & $9.4 \mathrm{c}$ & $9.9 \mathrm{c}$ & 0.00 & 7.5 \\
\hline SL & $2.3 \mathrm{a}$ & $1.6 \mathrm{~b}$ & $1.6 \mathrm{~b}$ & $1.5 \mathrm{~b}$ & $1.4 \mathrm{~b}$ & 0.00 & 11.2 \\
\hline RL & $4.2 \mathrm{a}$ & $2.1 \mathrm{c}$ & $2.2 \mathrm{bc}$ & $2.6 \mathrm{bc}$ & $2.8 \mathrm{~b}$ & 0.00 & 15.5 \\
\hline $\mathrm{DM}$ & $0.5 \mathrm{~b}$ & $0.6 \mathrm{~b}$ & $0.6 \mathrm{~b}$ & $0.6 \mathrm{ab}$ & $0.8 \mathrm{a}$ & 0.04 & 15.6 \\
\hline \multicolumn{8}{|c|}{ Caryocar brasiliense Camb. } \\
\hline GP & $96.0 \mathrm{ab}$ & $97.0 \mathrm{a}$ & $85.0 \mathrm{c}$ & $90.0 \mathrm{~b}$ & $86.0 \mathrm{c}$ & 0.01 & 5.7 \\
\hline GSI & $13.5 \mathrm{a}$ & $11.5 \mathrm{~b}$ & $9.8 \mathrm{c}$ & $10.4 \mathrm{bc}$ & $9.2 \mathrm{c}$ & 0.00 & 9.9 \\
\hline SL & $2.3 \mathrm{a}$ & $1.7 \mathrm{~b}$ & $1.2 \mathrm{c}$ & $1.4 \mathrm{bc}$ & - & 0.00 & 12.4 \\
\hline RL & $4.2 \mathrm{a}$ & $1.9 \mathrm{c}$ & $2.5 \mathrm{bc}$ & $3.0 \mathrm{~b}$ & - & 0.00 & 17.2 \\
\hline $\mathrm{DM}$ & $0.5 \mathrm{c}$ & $0.6 \mathrm{~b}$ & $0.7 \mathrm{ab}$ & $0.8 \mathrm{a}$ & - & 0.00 & 11.0 \\
\hline \multicolumn{8}{|c|}{ Pleroma candolleanum (Mart. ex DC.) Triana } \\
\hline GP & $96.0 \mathrm{a}$ & $90.0 \mathrm{a}$ & $93.0 \mathrm{a}$ & $90.0 \mathrm{a}$ & $84.0 \mathrm{a}$ & 0.07 & 5.9 \\
\hline GSI & $13.6 \mathrm{a}$ & $11.3 \mathrm{a}$ & $13.0 \mathrm{a}$ & $12.7 \mathrm{a}$ & $13.6 \mathrm{a}$ & 0.26 & 12.1 \\
\hline SL & $2.3 \mathrm{a}$ & $2.4 \mathrm{a}$ & $2.2 \mathrm{a}$ & $2.2 \mathrm{a}$ & $1.7 \mathrm{a}$ & 0.07 & 14.0 \\
\hline RL & $4.2 \mathrm{a}$ & $3.4 \mathrm{~b}$ & $2.9 \mathrm{~b}$ & $1.3 \mathrm{c}$ & $1.7 \mathrm{c}$ & 0.00 & 20.1 \\
\hline $\mathrm{DM}$ & $0.5 \mathrm{c}$ & $0.6 \mathrm{bc}$ & $0.6 \mathrm{bc}$ & $0.7 \mathrm{~b}$ & $0.8 \mathrm{a}$ & 0.00 & 12.1 \\
\hline \multicolumn{8}{|c|}{ Miconia albicans (SW.) Triana } \\
\hline GP & $92.0 \mathrm{a}$ & $84.0 \mathrm{a}$ & $80.0 \mathrm{a}$ & $79.0 \mathrm{a}$ & $84.0 \mathrm{a}$ & 0.22 & 9.6 \\
\hline GSI & $16.6 \mathrm{a}$ & $13.9 \mathrm{ab}$ & $9.7 \mathrm{c}$ & $11.3 \mathrm{bc}$ & $12.4 \mathrm{bc}$ & 0.00 & 14.7 \\
\hline SL & $2.8 \mathrm{a}$ & $1.8 \mathrm{~b}$ & - & $1.2 \mathrm{c}$ & - & 0.00 & 14.0 \\
\hline $\mathrm{RL}$ & $2.2 \mathrm{a}$ & $1.9 \mathrm{a}$ & - & $1.2 \mathrm{a}$ & - & 0.05 & 29.3 \\
\hline $\mathrm{DM}$ & $0.5 \mathrm{a}$ & $0.6 \mathrm{a}$ & - & $0.4 \mathrm{a}$ & - & 0.12 & 20.6 \\
\hline
\end{tabular}

Means followed by the same letter on the line, do not differ statistically by the Mann-Whitney test $(\mathrm{p}<0.05)$ or Duncan $(\mathrm{p}<0.05) \mathrm{CV}$ : coefficient of variation

In most cases, allelopathy does not affect the germination percentage, as it is considered the least sensitive parameter to the action of allelochemicals; however, it can interfere with the vigor of the seeds, acting on the speed of the germination process. In this sense, the results of the germination speed index (Table 3), demonstrate that the extracts of the studied species caused a significant reduction in the germination speed of the lettuce seeds in a manner inversely proportional to the concentration of the extracts, with the exception of $H$. obovatus and $P$. candolleanum, ranging from 1.1 to 23.9. The higher values of the germination speed index indicate greater speed and, therefore, less interference in the seed germination process. 
These results were similar to those obtained by Gatti et al. (2007), who did not find differences in the percentage of germination of lettuce seeds with aqueous extracts of leaves of Cerrado species; however, the authors report a significant reduction in the germination speed index. From an ecological point of view, seeds that germinate more slowly may show reduced initial development, therefore, are more susceptible to stress conditions, and are less able to compete for resources such as water and nutrients.

The leaf extracts of the species D. elliptica, C. laxum, H. obovatus, C. americana, Q. grandiflora, A. macrocarpon, C. brasiliense and M. albicans reduced the length of the aerial part of the lettuce seedlings with the increase of the concentrations of aqueous extracts.

The leaf extracts of the species of H. obovatus, D. alata, C. americana, Q. grandiflora, A. macrocarpon, C. brasiliense and $P$. candolleanum showed phytotoxic effect on the root system of lettuce seedlings. The higher the concentration of extracts of $H$. obovatus, Q. grandiflora and P. candolleanum species, the greater the inhibitory effect. In the case of the extracts of the species $C$. americana and $D$. alata, the root length did not differ between the concentrations of 25 to $100 \%$, although they differed from the control treatment $(0 \%)$.

There was greater inhibition in the length of the root in relation to the aerial part of the lettuce seedlings. For example, there was a reduction of about $71 \%$ in the root length in the minimum concentration of the extract of C. americana (25\%) when compared to the control treatment (0\%). However, the length of the aerial part of the lettuce seedlings was reduced by only $28 \%$ at maximum concentration (100\%). In this sense, the results agree with those obtained by Lopes et al. (2017) who reported a greater allelopathic effect of the aqueous extract of Lepidaploa aurea (Asteraceae) on the root length than on the aerial part of the target species (Lactuca sativa, Raphanus sativus, Solanum lycopersicum. and Sorghum bicolor).

Regarding the seedling dry mass variable, there was a phytotoxic effect dependent on the concentrations only for the species D. elliptica and C. laxum. Differences in dry mass were not observed in the species Himatanthus obovatus, Curatella americana and Dipteryx alata even though there was a decrease in the size of the roots and aerial part, this is possibly due to the low precision of the scale used.

The results of the bioassays carried out by Imatomi et al. (2013) with 15 species of the Myrtaceae family proved that each donor species behaves differently in relation to allelopathic activity, varying the degree of phytotoxic effect, regardless of the species from which the extract was obtained.

The allelopathic response index (RI) is an important indicator of allelopathic effects. In the present study, the RI values were always negative, which means that the allelopathic effects of the aqueous extracts were inhibitory in lettuce seeds and, in most cases, dose dependent (see some examples in Figure 1).
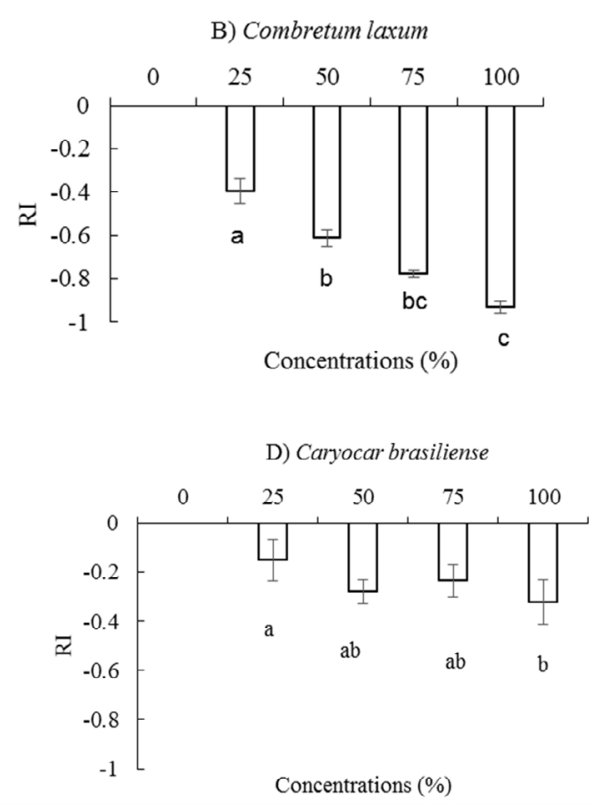

Figure 1. Allelopathic response index (IR) of lettuce seeds (Lactuca sativa L.) to different concentrations of aqueous leaf extracts from Cerrado species. Chapada dos Guimarães/MT, 2018. Means followed by the same letter do not differ significantly by the Tukey's test $(\mathrm{p}<0.05)$. The vertical bars indicate the standard error of the mean. 
The species C. laxum had an RI close to - 1.0 at maximum concentration (100\%) (Figura 1B), showing a strong negative allelopathic effect. Studies have shown negative RI for the seed germination data of target species, proportional to the concentration of the extracts (Borella et al., 2011).

The Fourier transform infrared spectrum (FTIR) was obtained to enable the identification of functional groups of the active compounds of the species with the greatest allelopathic potential (D. elliptica, C. laxum, C. brasiliense and Q. grandiflora) based on the peak values in the region of infrared radiation. The results (absorption bands) obtained via FTIR and identified functional groups are shown in Table 4. The FTIR spectrum confirms the presence of alcohols, phenols, alkanes, alkenes, aromatics, hydroxyls, carboxylic acid and amines in the aqueous leaf extracts of these four Cerrado species.

Table 4. FTIR absorption bands and functional groups present in the aqueous leaf extracts of Davilla elliptica, Combretum laxum, Caryocar brasiliense and Qualea grandiflora. Chapada dos Guimarães, 2019.

\begin{tabular}{|c|c|c|c|c|c|}
\hline \multirow{2}{*}{$\begin{array}{l}\text { Functional } \\
\text { groups }\end{array}$} & D. elliptica & C. laxum & C. brasiliense & Q. grandiflora & \multirow{2}{*}{ Type of vibration } \\
\hline & \multicolumn{4}{|c|}{ Band $\left(\mathrm{cm}^{-1}\right)$} & \\
\hline Alcohol & $1.042-1.072$ & $1.034-1.111$ & $1.042-1.103$ & 1.042 & C-O stretch ${ }^{1}$ \\
\hline Phenol & 1.234 & 1.204 & 1.227 & 1.211 & C-O stretch ${ }^{2}$ \\
\hline Aromátic amine & 1.366 & 1.335 & 1.343 & 1.335 & C-N stretch ${ }^{1}$ \\
\hline Amine & 1.512 & - & 1.520 & 1.504 & $\mathrm{~N}-\mathrm{H}$ stretch asym \\
\hline Alkene & 1.620 & 1.605 & 1.612 & 1.612 & $\mathrm{C}=\mathrm{C}$ stretch ${ }^{4}$ \\
\hline Aromatic & 1.443 & 1.443 & - & - & $\mathrm{C}=\mathrm{C}$ stretch ${ }^{6}$ \\
\hline Alkane & 2.924 & $2.855-2.924$ & 1.450 & $1.366-1.450$ & $\begin{array}{l}\mathrm{C}-\mathrm{H} \text { stretch } \mathrm{sp}^{3} \text { hybridization methylene } \\
\text { symmetrical angular deformation of } \mathrm{CH}_{3}\end{array}$ \\
\hline Hydroxyl & 3.372 & 3.271 & 3.332 & 3.325 & $\mathrm{O}-\mathrm{H}$ hydrogen bonding stretch $\mathrm{h}^{1,3}$ \\
\hline Carboxilic acid & - & - & 1.697 & 1.697 & $\mathrm{C}=\mathrm{O}$ stretch ${ }^{5}$ \\
\hline Aromatic & $764-826$ & - & $640-818$ & $763-918$ & Angular deformation out of plane $\mathrm{C}-\mathrm{H}$ \\
\hline
\end{tabular}

${ }^{1}$ Jemilugba et al., (2019); ${ }^{2}$ Oliveira et al. (2016); ${ }^{3}$ Eassa et al., (2018); ${ }^{4}$ Khan et al., (2018); ${ }^{5}$ Kpemissi et al., (2019)

The broadband centered at $\sim 3,300 \mathrm{~cm}^{-1}$ can be attributed to the lengthening of the - $\mathrm{OH}$ bond in proteins, fatty acids, carbohydrates and lignin, present in plants. The $-\mathrm{OH}$ elongation can also be laid to the presence of adsorbed water in the sample (Amorim et al., 2016). In all spectra, the - $\mathrm{OH}$ band was very long, covering important stretches of $\mathrm{CH}_{2}$ and $\mathrm{CH}_{3}$ that would assist in the identification of other functional groups in the infrared spectrum of the extracts.

The results of the TLC show that the species D. elliptica and C. brasiliense presented the four classes studied (Table 5). These results agree with those described in the literature at the level of genus and/or species (Costa et al. 2008; AyubaAbdul et al., 2015; Carvalho et al., 2015; Rodrigues et al., 2019)

Table 5. Identification of classes of secondary compounds in aqueous leaf extracts of Davilla elliptica, Combretum laxum, Caryocar brasiliense and Qualea grandiflora. Chapada dos Guimarães, 2019.

$\begin{array}{ccccc}\text { Class } & \text { Davilla elliptica } & \text { Combretum laxum } & \text { Caryocar brasiliense } & \text { Qualea grandiflora } \\ \text { Phenol } & + & + & + & + \\ \text { Alkaloids } & + & - & + & - \\ \text { Flavonoids } & + & + & + & + \\ \text { Terpenoids } & + & + & +\end{array}$

(-) absent; (+) present

Phenols have strong phytotoxic activity that affects plant structure and is one of the most deeply studied functional groups (Macías et al. 2019). Research indicates that they significantly interfere with several important plant enzymes linked to plant physiological processes. Some phenolic compounds with recognized allelopathic activity are ferulic acid, caffeic acid, gallic acid and quercetin (Latif et al., 2017).

The presence of the phenol group in the extract of $C$. laxum (Table 4 and Table 5) reinforces the results of the allelopathic potential obtained from the bioassays (Table 3). 
Flavonoids are water-soluble compounds due to the presence of sugars linked to the structure; this characteristic increases their potential in the production of future herbicides (Macías et al., 2019). Likewise, flavonoids are a class characteristic of the species of the genus Combretum (Martini et al., 2004); however, in this study they were not identified in the aqueous extract of the leaves of the species C. laxum.

The infrared results of the species confirm the presence of the phenol group (Table 4), important in the molecular structure of the flavonoids next to the aromatic rings joined to a hydroxyl group. Therefore, possibly the non-identification of the class, using thin layer chromatography, may be due to the low sensitivity of the technique used or the low concentration in the aqueous extract. It is suggested the use of other developers, such as lead acetate (II) and organic solvents such as ethanol at the time of the extraction of allelochemicals from C. laxum, which allow the identification of flavonoids (Bokhad \& Rothe, 2012).

Alkaloids form the most important group among allelochemicals that contain nitrogen in their composition; most of them are derived from amino acids, but can be synthesized via terpenoids. They are the third most studied allelochemical in the last twelve years, after phenols and flavonols (Macías et al., 2019).

The functional groups and classes of compounds reported in the aqueous extracts evaluated exhibit significant phytotoxic properties that support the importance of these plants in the development of sustainable alternatives in weed control.

The effects of the aqueous extracts of the leaves of the studied species on the seeds and seedlings of lettuce are possibly the result of the action of the allelochemicals present in the extracts, since, in fact, phytotoxic effects (inhibitory) were confirmed in the germination and initial growth of the seedlings. However, phytochemical characterization using advanced chemical analysis techniques is necessary to obtain detailed and complete information on the constituents of the extracts, which facilitate the identification of allelochemicals responsible for phytotoxic activity.

Thus, the precise knowledge of the allelochemicals of the aqueous extracts of the leaves of the studied species can serve as a basis for conducting more in-depth studies that aim to evaluate the allelopathic potential of these species in field conditions, using invasive and herbicide-resistant species as target species. .

\section{CONCLUSIONS}

Under laboratory conditions, of the ten species evaluated, the aqueous leaf extracts of Davilla elliptica, Combretum laxum, Caryocar brasiliense and Qualea grandiflora showed greater phytotoxic activity in the germination and initial development of Lactuca sativa L. seedlings.

The preliminary analysis of the chemical composition of the aqueous extracts indicates the presence of functional groups such as alcohols, phenols, alkanes, amines, alkenes, aromatics, hydroxyl, carboxylic acid and secondary compounds with phytotoxic activity such as phenols, alkaloids, flavonoids and terpenes.

\section{SUBMISSION STATUS}

Received: 26 Feb. 2021

Accepted: 11 Jun. 2021

Associate editor: Rodrigo Studart Corrêa (1)

\section{CORRESPONDENCE TO}

\section{Sharmely Hilares Vargas}

Universidade Federal de Mato Grosso, Programa de Pós-Graduação em Agricultura Tropical, Cuiaba, MT, Brasil.

e-mail: sharhilares@gmail.com

\section{REFERENCES}

Amorim DJ, Rezende HC, Oliveira EL, Almeida ILS, Coelho NMM, Matos TN, et al. Characterization of Pequi (Caryocar brasiliense) shells and evaluation of their potential for the adsorption of $\mathrm{PbII}$ Ions in aqueous systems. Journal of the Brazilian Chemical Society 2016; 27: 16-623.

Ayers RS, Westcot DW. Water quality for agriculture. Rome: Food and Agriculture Organization of the United Nations; 1999.

Ayuba-Abdul MJ, Adelanwa MA, Alao SEL, Anamayi SE. Antifungal potential and phytochemical screening of Combretum molle leaves and stembark against Macrophomina phaseolina (Tassi) Goid. International Journal of Scientific and Engineering Research 2015; 6: 716-721.

Bokhad MN, Rothe SP. Preliminary phytochemical investigation of Combretum albidum G. Don, An ignored medicinally important liana. Journal of experimental sciences 2012, 3: 1-4.

Borella J, Martinazzo EG, Aumonde TZ. Atividade alelopática de extratos de folhas de Schinus molle L. sobre a germinação e o crescimento inicial do rabanete. Revista Brasileira de Biociências 2011; 9: 398-404.

Brasil. Ministério da Agricultura, Pecuária e Abastecimento. Regras para análise de sementes. Secretaria de Defesa Agropecuária. Brasilia: Mapa/ACS, 2009.

Carvalho LSD, Pereira KF, Araújo EGD. Características botânicas, efeitos terapêuticos e princípios ativos presentes no pequi (Caryocar brasiliense). Arquivos de Ciências da Saúde da UNIPAR 2015; 9: 147-157.

Chaves JN, Mazutti M, Zabot G, Tres M. Ação bioherbicida de caldo fermentado de Phoma dimorpha em sementes e plantas de Senna obtusifolia. Pesquisa Agropecuária Tropical 2019; 50: 1-8.

Costa ES, Hiruma-Lima CA, Lima EO, Sucupira GC, Bertolin AO, Lolis SF, et al. Antimicrobial activity of some medicinal plants of the cerrado, brazil. Phytotherapy research 2008; 22: 705-707. 
Eassa SMH, Balah AM, Afiah SA, El-Hadidy AE. Allelopathic activity of Sorghum bicolor root parts and exudates on Bipolaris sorokiniana. Journal of Crop Protection 2018; 7: 259-271.

Gatti AB, Pérez SCDA, Ferreira AG. Avaliação da atividade alopática de extratos aquosos de folhas de espécies de Cerrado. Revista Brasileira de Biociências 2007; 5: 174-176.

Gatti AB, Pérez SCJGD, Lima MIS. Atividade alelopática de extratos aquosos de Aristolochia esperanzae O. Kuntze na germinação e no crescimento de Lactuca sativa L. e Raphanus sativus L. Acta Botanica Brasilica 2004; 18: 459-472.

Gupta PC. Herbicides and fungicides. In: Gupta RS. Reproductive and developmental toxicology, Second Edition. Kentucky: Academic Press, 2017. p. 657-679.

Imatomi M, Novaes P, Gualtieri SCJ. Interspecific variation in the allelopathic potential of the family Myrtaceae. Acta Botanica Brasilica 2013; 27: 54-61.

Jemilugba OT, Sakho EHM, Parani S, Mavumengwana V, Oluwafemi OS. (FTIR) Green synthesis of silver nanoparticles using Combretum erythrophyllum leaves and its antibacterial activities. Colloids and Interface Science Communications 2019; 31: 100191.

Khan S, Shinwari MI, Haq A, Ali KW, Rana T, Badshah M, et al. Fourier-transform infrared spectroscopy analysis and antifungal activity of methanolic extracts of Medicago parviflora, Solanum Nigrum, Melilotus alba and Melilotus indicus on soil-borne phytopathogenic fungi. Pakistan Journal of Botany 2018; 50: 1591-1598.

Kpemissi M, Eklu-gadegbeku K, Veerapur VP, Potârniche AV, Adi $\mathrm{K}$, Vijayakumar S, et al. (FTIR) Antioxidant and nephroprotection activities of Combretum micranthum: A phytochemical, in-vitro and ex-vivo studies. Heliyon 2019; 5: e01365.

Latif S, Chiapusio G, Weston LA. Allelopathy and the role of allelochemicals in plant defence. In: Becard, G. Advances in botanical research: How plants communicate with their biotic environment. v.82. Castanet-Tolosan: Academic Press; 2017. p.19-54.

Londres F. Agrotóxicos no Brasil: uma guia para ação em defesa da vida. Rio de Janeiro: AS-PTA Assessoria e Serviços a projetos em Agricultura Alternativa; 2011.
Lopes PG, Salles KA, Oliveira SCC, Sampaio AB, Schmidt IB. Evidence of phytotoxicity in a fast-growing shrub useful for savanna restoration in Central Brazil. Brazilian Journal of Botany 2017; 40: 643-649.

Macías FA, Mejías FJR, Molinillo JMG. Recent advances in allelopathy for weed control: from knowledge to applications. Pest management science 2019; 75: 2413-2436.

Maguire JD. Speed of germination-aid in selection evaluation for seedling emergence and vigor. Crop Science 1962; 2: 176-177.

Martini ND, Katerere DR, Eloff JN. Seven flavonoids with antibacterial activity isolated from Combretum erythrophyllum. South African Journal of Botany 2004; 70: 310-312.

OECD; FAO. 2015. OCDE-FAO Perspectivas Agrícolas 2015-2024. París: OECD Publishing. DisponÍvel em:< http://dx.doi.org/10.1787/ agr_outlook-2015-es>. Acesso em: 6 nov. 2019.

Oliveira RN, Mancini MC, Oliveira FCSD, Passos TM, Quilty B, Thiré RMDSM, et al. FTIR analysis and quantification of phenols and flavonoids of five commercially available plants extracts used in wound healing. Matéria (Rio de Janeiro) 2016; 21: 767-779.

Pereira JC, Paulino CLDA, Granja BDS, Santana AEG, Endres L, De Souza RC. Allelopathic potential and identification of secondary metabolites in extracts of Canavalia ensiformis L. Revista Ceres 2018; 65: 243-252.

Rodrigues D, Pereira G, Silva A, Santos M, Demuner A, Oliveira P. Perfil Fitoquímico de Plantas Daninhas de Pastagens do Cerrado Brasileiro. Planta Daninha 2019; 37: e019181108.

Vargas SH, Coelho MDFB, Cowo ES, Murillo HM, Spiller C. Phytotoxic potential of aqueous leaf extract of Tocoyena formosa and Rudgea viburnoides. Revista Ceres 2019; 66: 380-386.

Wandscheer ACD, Borella J, Bonatti LC, Pastorini LH. Atividade alelopática de folhas e pseudofrutos de Hovenia dulcis Thunb. (Rhamnaceae) sobre a germinação de Lactuca sativa L. (Asteraceae). Acta Botanica Brasilica 2011; 25: 25-30.

Williamson GB, Richardson D. Bioassays for allelopathy: measuring treatment responses with independent controls. Journal of chemical ecology 1988; 14: 181-187. 